\title{
Maxillary Osteomyelitis by Actinomyces in a Child
}

\author{
Osteomielitis Maxilar por Actinomyces en un Niño
}

\begin{abstract}
Nicolau Conte Neto1; Waldner Ricardo Souza de Carvalho2; Salete Martins Lima Conceição;
\end{abstract} Lucas Martins de Castro e Silva ${ }^{4} \&$ Eduardo Hochuli Vieira ${ }^{4}$

NETO, C. N.; CARVALHO, W. R. S.; CONCEIÇÃO, S. M. L.; SILVA, L. M. C. \& VIEIRA, E. H. Maxillary osteomyelitis by actinomyces in a child. Int. J. Odontostomat., 12(1):15-20, 2018.

ABSTRACT: Actinomycosis is a bacterial infection caused by Actinomyces species, which usually affect the soft tissues of the cervicofacial region of adult males. Clinically, it's characterized by a slow-growing indurated mass, especially in the submandibular area. However, in a few cases, the jaws bones can be affected developing osteomyelitis characteristics. The aim of this paper is to report a rare clinical case of Actinomycotic Osteomyelitis affecting the maxilla of a child, involving the maxillary sinus, orbital and zygomatic areas that was treated by the association of antibiotic therapy and surgical debridement. The patient's 2 years follow-up was uneventful and no signs of the lesion recurrence.

KEY WORDS: actinomycosis, osteomyelitis, maxilla.

\section{INTRODUCTION}

Actinomycosis is a bacterial infection caused by Actinomyces species, an anaerobic gram-positive filamentous rod that belongs to resident oral microbiota (Kaplan et al., 2009). Actinomyces israelii is by far the most common cause of actinomycotic infection, but other oral species of Actinomyces have also been implicated in human infections, such as $A$. viscosus and A. naeslundii (Curi et al., 2000). Anatomically, the actinomycosis can be classified as cervicofacial, thoracic, and/or abdominal types. Among them, cervicofacial actinomycosis is the most common type (Miller \& Haddad, 1998) and most cases are of odontogenic origin (Sharkawy, 2007).

In its classic form, actinomycosis commonly involves the soft tissues of the jaw or neck as a slowgrowing indurated mass, especially in the submandibular area. However, in a few cases the jaws bone tissues can also be affected, where mandible $(53.6 \%)$ is more affected than maxilla (5.7 \%) (Miller \& Haddad), where it can affect the maxillary sinus (Cohn et al., 2017). Within this context, the aim of this paper is to report an unusual and aggressive osteomyelitis triggered by Actinomyces species in a child maxilla.

\section{CLINICAL REPORT}

A 12-year-old Caucasian girl was admitted to the Department of Oral and Maxillofacial Surgery of the Araraquara Dental School - Unesp, with a previous diagnosis of orbital cellulitis of odontogenic nature, evolving for 3 days. Review of the patient's medical history did not reveal any co-morbidities or medicines in use.

During clinical examination, a mild temperature elevation was present and the patient complained about a pressure around the left maxillary second premolar with intermittent painful symptoms. At that moment, a marked left periorbital tender edema and erythema was evident (Fig. 1), with no ocular impairment, as well a painful left palatal swelling with cellulite aspects in the vicinity of the referred tooth which presented a long-lasting extensive tooth decay (Fig. 2) and absence of tooth vitality according to pulp tests. Otherwise, the patient exhibited reasonable oral hygiene and the head-and-neck examination was unremarkable, with no evidence of any cervical lymphadenopathy.

On panoramic radiographic examination, no pathological changes could be noticed in bone tissues

\footnotetext{
${ }^{1}$ Federal State University of Para, School of Dentistry, Department of Oral Surgery, Augusto Correa Street, 01, 66075-110, Belem - Para, Brazil. 2 João de Barros Barreto University Hospital- Department of Oral Pathology, Mundurucus Street, 4487, 66073-000, Belem - Para, Brazil.

${ }^{3}$ Federal State University of Para, School of Dentistry, Graduation student, Augusto Correa Street, 01, 66075-110, Belem - Para, Brazil.

${ }^{4}$ São Paulo State University, Department of Diagnosis and Surgery, Humaita Street, 1680, 14801-903, Araraquara - Sao Paulo, Brazil.
} 


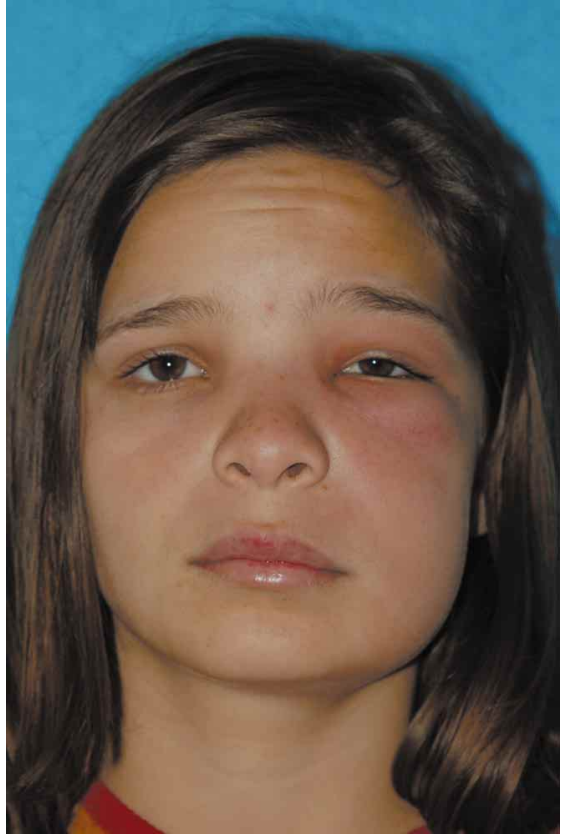

Fig. 1. Extra oral view showing periorbital swelling and erythema.

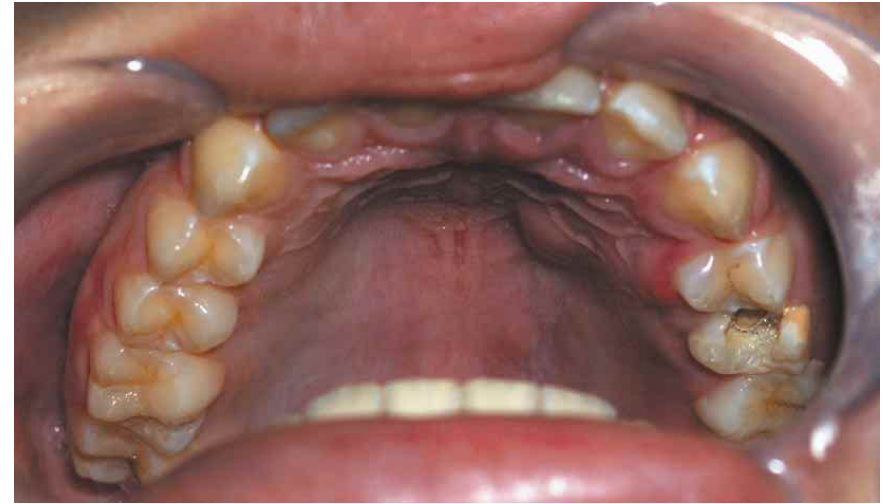

Fig. 2. Clinical appearance at initial examination reveling second superior premolar with extensive tooth decay and palatal swelling.

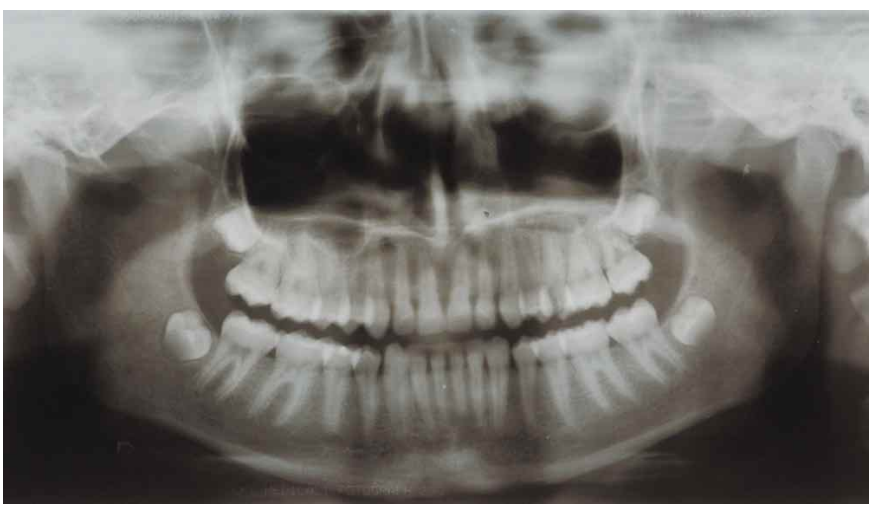

Fig. 3. Panoramic Radiograph demonstrates the absence of infection signals.

(Fig. 3) and the previous acute odontogenic infection diagnosis was confirmed. In this way, the treatment plan included antibiotic therapy with cephalothin (Keflin $®, A B L$, Sao Paulo - Brazil) and metronidazole (Flagyl@, Sanofi, Sao Paulo-Brazil) associated with the extraction of the left maxillary second premolar and intra-oral drainage through general anesthesia.

During the surgery, it was possible to detect a raised mobility of all left maxillary teeth associated with a purulent discharge and gingival bleeding of the second premolar after clinical manipulation. Initially, the aspiration puncture of the swelling was done using a 20-gauge needle and the purulent material around the

tooth was collected, both were sent to culture analysis. After that, the tooth extraction wasperformed and a grayish color aspect of the maxillae with no socket bleeding could be noticed. Due to these abovementioned clinical findings, the exposition of the left maxilla side was performed (Fig. 4a).
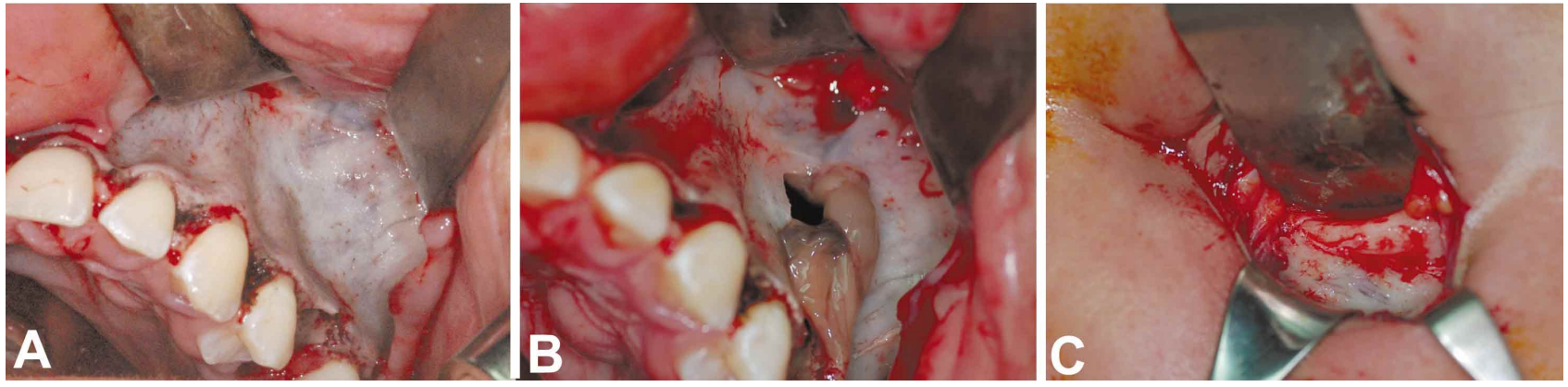

Fig. 4. a) Intraoral view showing a grayish maxillae with no bleeding; b) Clinical aspect of maxillary sinusal mucosa; c) Infraorbital approach revealing the bone necrosis extending near to the infraorbital rim. 
After maxillae stripping, it was observed that the maxillae pathological aspect was extended to the maxillary sinus, infraorbital rim and orbital floor (Fig. 4c). Besides, bone revealed an avascular necrosis aspect and the maxillary sinus mucosa presented characteristics of sinusitis (Fig. 4b). For this reason, it was decided to perform a sinusectomy of the maxillary membrane associated with extraction of all teeth on the left side followed by the necrotic bone debridement until bleeding bone surface was detected (Fig. 5). The specimens collected were sent to histopathological examination.

For technical reasons the culture for anaerobic was not done. The aspiration puncture material did not reveal bacterial growth, but the results of the purulent material analysis revealed the presence of Streptococcus

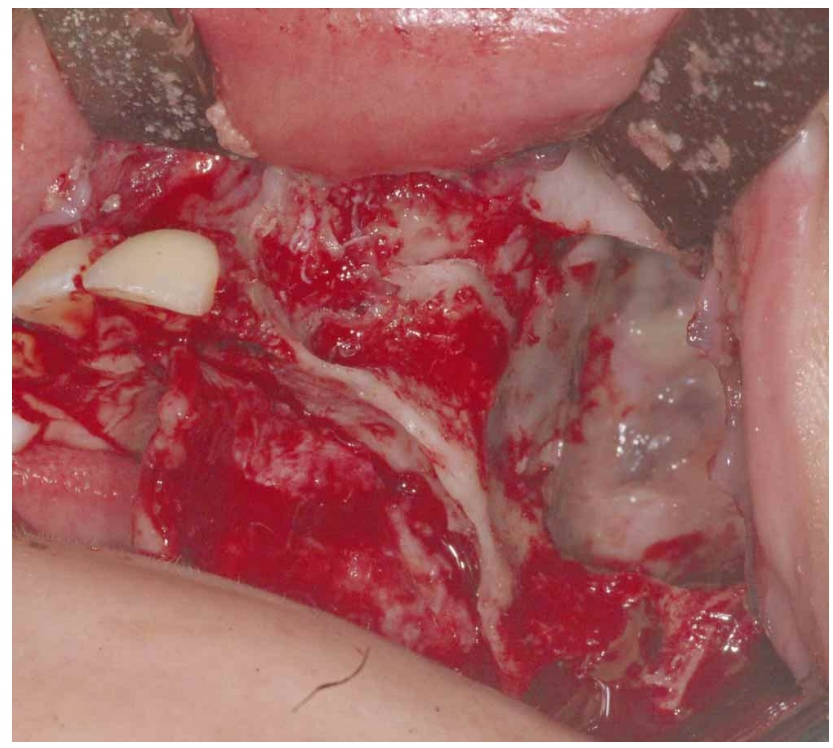

Fig. 5. Maxillae appearance after tooth and bone necrotic removal. viridans, Neisseria mucosa, and Corynebacterium sp. From the histopathological analysis of bone specimens it was possible to identify the presence of Actinomyces colonies and the maxillary sinus mucosa revealed necrotizing chronic sinusitis characteristics (Fig. 6). Give these findings, the diagnosis of Actinomycotic Osteomyelitis could be established.

From the results of histopathological examination it was decided to change the initial antibiotics prescribed to cephalexin (Keflex®, Bago, Sao Paulo - Brazil) and this regimen was maintained during 40 days. The healing progressed uneventful, and within 2 years after the surgery the soft tissue remaining with normal aspect and without any signs of inflammatory or infectious processes (Fig. 7a). On radiographic analysis there are no signs of recurrence (Fig. 8) and the patient was rehabilitated with a removable partial denture (Fig. $7 b$ ).

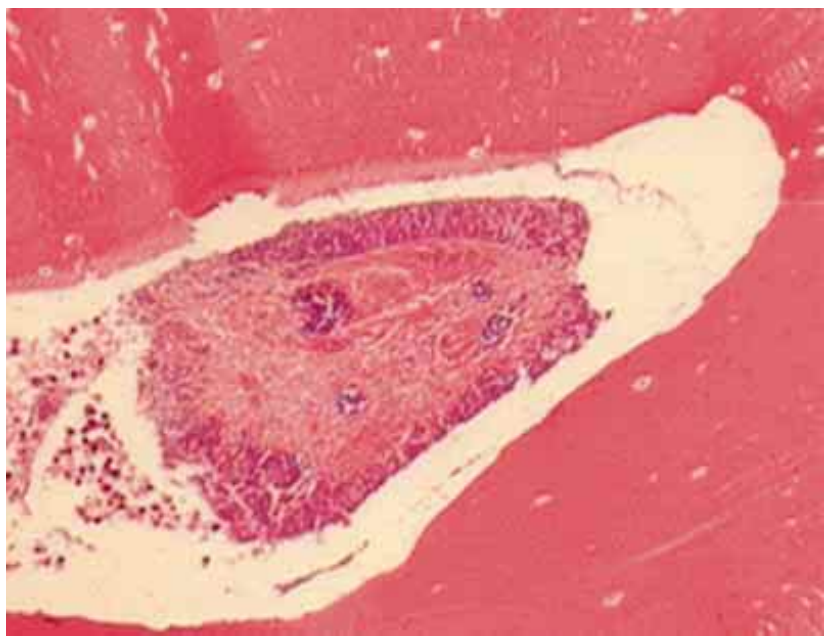

Fig. 6. Hematoxylin and eosin stained section showing bone necrosis associated with Actinomyces colonies.

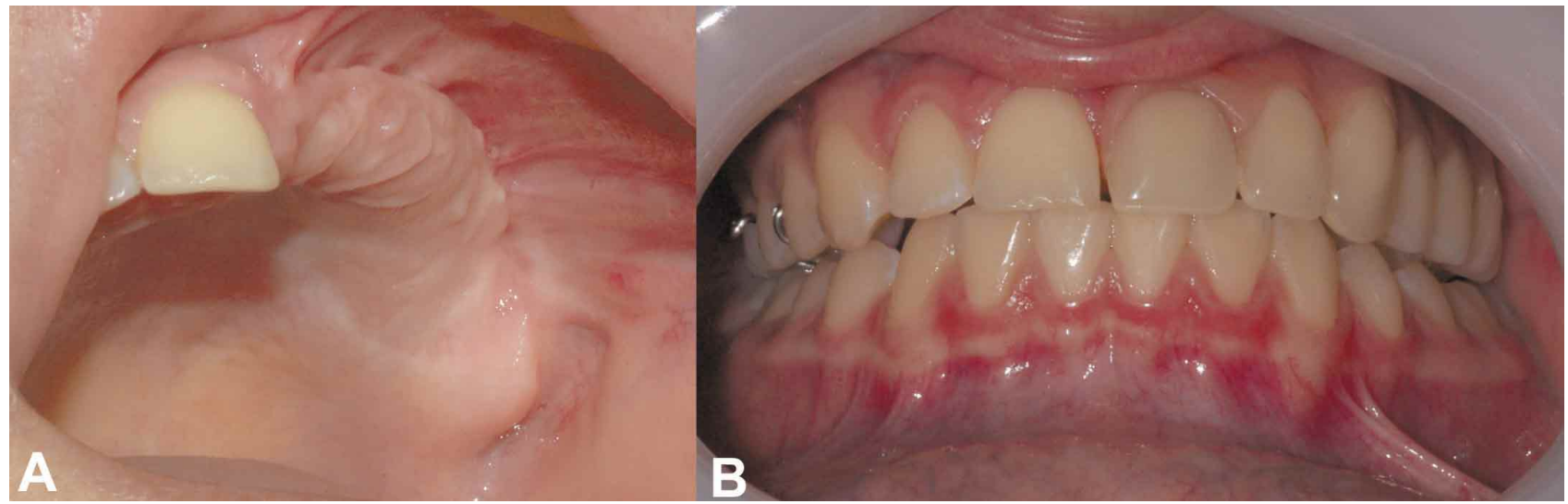

Fig. 7. A) Postoperative of two year revealing oral mucosa with normal aspect; B) Oral patient rehabilitation with partial removal prosthesis. 


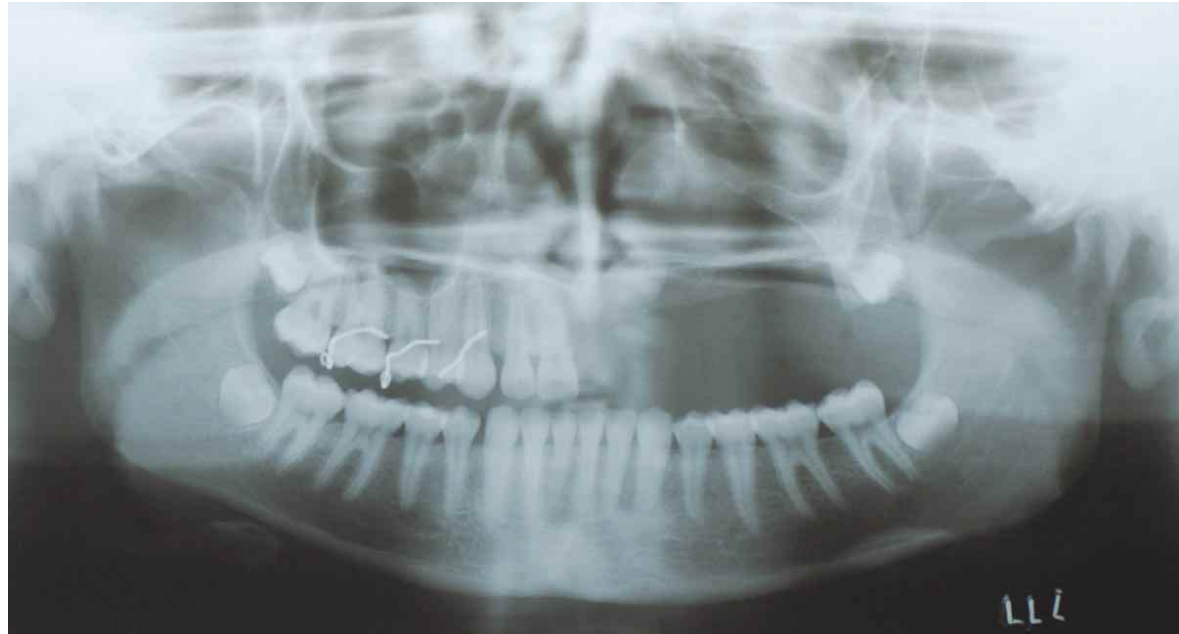

Fig. 8. Two year postoperative panoramic radiograph.

\section{DISCUSSION}

The resident human oral microbiota is composed by a sort of microorganisms, including Actinomyces species, which represent a human commensal that is usually associated with a minimal potential for invasion and lack of virulence (Goldberg, 2003). The exact pathophysiology of actinomycotic osteomyelitis is unclear; however it is suggested that inflammation begins when the normal composition of the microbial flora is disturbed (Meethal et al., 2016), resulting in serious infectious process that develops for over half of reported cases in the cervicofacial region. Of them only $0.5-9.0 \%$ of the reports affect the maxillae (Esson \& Lee, 2005).

Several predisposing factors to Actinomyces infection have been described in the literature, including: 1- systemic diseases, such as diabetes and other immunosuppression conditions (Wadhera etal., 2008); 2 - disruption of the oral mucosa by oral trauma or dental manipulation (Hirshberg et al., 2003; Finley \& Beeson, 2010); 3- poor oral hygiene and dental diseases, such as caries, gingivitis and infectionwhen the secondary teeth is erupting (Feder, 1990); 4necessity of an anaerobic environment, such as is provided by devitalized tissue (Wadhera et al.) and a polymicrobial environment which work to reduce local oxygen tension (Sharkawy).

The jaws bone tissue, although rare, can also be affected, especially without concomitant soft tissue involvement. Usually, it is a secondary process, since these bacteria reach the bone from the spread of the infection from adjacent soft tissues, extraction or fractures sites (Esson \& Lee). This paper seems to be in agreement with this assumption and it is reasonably to believe that these bacteria gained access to the periapical region of the maxillary bone trough the tooth root after pulp necrosis where they usually establish a chronic progressive infection, which can result either in periostitis as well areas of bone destruction.

Progressive bony destruction and the formation of sequestrate are hallmarks of osteomyelitis (Manpreet et al., 2017). In these cases, the clinical manifestations are often subtle, and the diagnosis is typically delayed for weeks to months (Robinson et al., 2005), which allows the increase of bone destruction, such in the present report. Moreover, in the pediatric population, actinomycosis is rare, and a low level of suspicion may cause diagnostic confusion and delay in treatment (Foster et al., 1993). Clinicians can look to the history for clues, including a preceding dental procedure or infection, to suggest an unconventional pathogen such as actinomyces.

In our report, although a kind of indurated swelling was found, the soft tissue consistence was result of the cellulitis process, since there was no fibrosis formation in this report which is a classical characteristic of this disease, especially in chronic course (Sharkawy). Otherwise, cutaneous fistulas and hard facial swelling are unusual in maxillary cases (Rubin \& Krost, 1995). For these reasons, it is reasonably to believe that the soft tissue involvement in our patient was probably secondary to a concomitant odontogenic infection due to other bacteria rather than Actinomyces, which could be supported by the culture findings. This assumption could explain the lack of correspondence of the large extension of bone necrosis, involving maxillary sinus and zygomatic bone with the short period of oral and facial swelling beginning.

Cervicofacial actinomycosis has a high prevalence for males, affecting adult patients (Bartkowski et al., 1998). However, in rare situations, pediatric population also can be involved, exhibiting 
also prevalence for male and mandible (Robinson et al.), which differs from our report. However, the male predominance in actinomycosis is less pronounced in the pediatric age group (Pulverer et al., 2003). There are only a few cases reported in the literature of primary actinomycosis arising within the maxilla. Although rarely seen in dental practice, actinomycosis of the oral cavity is a highly significant condition due $\mathrm{o}$ its aggressive and locally destructive nature.

Depending on the clinical and imaging presentation of the $\mathrm{AO}$, the differential diagnosis usually involves infectious process or malignancy (Bartkowski et al.). The diagnostic confirmation can be achieved by the association of clinical characteristics with the recovery of Actinomyces species from appropriately cultured specimen (Goldberg) and/or, as in our report, histological analysis of infected tissue (Hall, 2008), which is probably the most common technique to obtain the definitive diagnosis of actinomycosis (Curi et al.; Wadhera et al.), that contains the classic sulfur granules on histological analysis (Vorasubin et al., 2013), given the difficulty of isolate Actinomyces species in pure culture (Jacobs \& Schutze, 2000) due to concomitant aerobic and anaerobic bacteria overgrowth (Curi et al.).

Definitive diagnosis based on cultures is not often positive but histopathology is still the most reliable diagnostic aid (Gannepalli et al., 2015). Diagnosis of actinomycotic osteomyelitis is often based on clinical, radiological and microscopic evidence, rather than bacteriological culture and identification. This is due to numerous problems associated with culture, such as inability to maintain anaerobic conditions and overgrowth of other bacteria (Meethal et al.).

In fact, the clinical correlation play a fundamental role in diagnosis process, since the presence of $A$. israelii does not unequivocally confirm its role as the etiologic agent in an infection; it may represent contamination or commensal growth (Goldberg). Moreover, it is relevant to state that usually others bacteria are found concomitantly with Actinomyces (Pulverer et al.). Infection presents itself as granulomatous inflammatory response with central suppurative necrosis consisting of aggregates of bacterial filaments surrounded by neutrophils (Gannepalli et al.). Thus, it is difficult to state if they are the main responsible for the infection, or, even, if they colonized the bone already necrotized.

In this report, the treatment performed was according the literature recommendation that is a high and prolonged dose of antibiotics, associated with drainage and surgical intervention (Rubin \& Krost; Lerner, 1998; Bartkowski et al.) for excision of necrotic tissue and curettage of affected bony tissue (Bennhoff, 1984). This is necessary to remove the necrotic bone, which is an excellent anaerobic growth medium that could impair the antibiotics from penetrating in the lesion and reach the colonies (Rubin \& Krost; Goldberg). Sessions with hyperbaric oxygen to improve both extra and intraoral habitat and enhance the reparative effect (Moreno Villalobos et al., 2012).

The minimal duration of antimicrobial therapy for osteomyelitis caused by Actinomyces is not clear. Although there is no evidence that prolonged courses of antimicrobial therapy increase the chance of cure it is usually recommended between 2 and 3 month of antibiotics (Robinson et al.),

The management of actinomycotic osteomyelitis is surgical debridement of necrotic tissue combined with antibiotics for 3-6 months (Gannepalli et al.), and the antibiotics include penicillin, tetracycline, clindamycin, or cephalexin (Barnard et al., 1996), which was the main antibiotic prescribed in the present case report. The term "cure" is not used for osteomyelitis because the infection may recur years after apparent successful treatment of the disease, if the patient suffers new trauma to the involved area, or the host response to the infection is suppressed (Manpreet et al., 2017).

\section{CONCLUSION}

Actinomycosis is a serious bacterial infection that can affect jaw bones and present an aggressive course, especially in pediatric patients. The present paper reports an unusual osteomyelitis of maxilla with involvement of maxillary sinus trigger by a long-term periapical infection, which resulted in an extensive loss of bone tissue. Although it was successfully treated by surgical debridement plus antibiotic therapy, inpediatric patients, the oral rehabilitation is limited given the skeletal growing course.

\section{ACKNOWLEDGEMENTS}

The authors gratefully acknowledge Nicolino Lia Neto, a physician specialist in Anatomo-pathology of Araraquara/Sao Paulo/Brazil. 
NETO, C. N.; CARVALHO, W. R. S.; CONCEIÇÃO, S. M. L.; SILVA, L. M. C. \& VIEIRA, E. H. Osteomielitis maxilar por actinomyces en un niño. Int. J. Odontostomat., 12(1):1520, 2018.

RESUMEN: La actinomicosis es una infección bacteriana causada por la especie Actinomyces, que generalmente afecta los tejidos blandos de la región cervicofacial de los hombres adultos. Clínicamente, se caracteriza por una masa endurecida de crecimiento lento, especialmente en la zona submandibular. Sin embargo, en algunos casos, los huesos de las mandíbulas pueden ser afectados desarrollando características de osteomielitis. El objetivo de este trabajo es reportar un caso clínico poco frecuente de osteomielitis actinomicótica que afecta el maxilar de un niño, envolviendo el área del seno maxilar, y zonas orbitales y cigomáticas que fueron tratadas con la asociación de terapia con antibióticos y desbridamiento quirúrgico. El seguimiento del paciente por 2 años ocurrió sin incidentes y sin signos de recidiva de las lesiones.

PALABRAS CLAVE: actinomicosis, osteomielitis, maxilar.

\section{REFERENCES}

Barnard, D.; Davies, J. \& Figdor, D. Susceptibility of Actinomyces israelii to antibiotics, sodium hypochlorite and calcium hydroxide. Int. Endod. J., 29(5):320-6, 1996.

Bartkowski, S. B.; Zapala, J.; Heczko, P. \& Szuta, M. Actinomycotic osteomyelitis of the mandible: review of 15 cases. $J$. Craniomaxillofac. Surg., 26(1):63-7, 1998.

Bennhoff, D. F. Actinomycosis: diagnostic and therapeutic considerations and a review of 32 cases. Laryngoscope, 94(9):1198-217, 1984.

Cohn, J. E.; Lentner, M.; Li, H. \& Nagorsky, M. Unilateral maxillary sinus actinomycosis with a closed oroantral fistula. Case Rep. Otolaryngol., 2017:7568390, 2017.

Curi, M. M.; Dib, L. L.; Kowalski, L. P.; Landman, G. \& Mangini, C. Opportunistic actinomycosis in osteoradionecrosis of the jaws in patients affected by head and neck cancer: incidence and clinical significance. Oral Oncol., 36(3):294-9, 2000.

Esson, M. \& Lee, J. Actinomycosis in the maxilla-A case report. Int. J. Oral Maxillofac. Surg., 34 Suppl., 1:132, 2005.

Feder, H. M. Jr. Actinomycosis manifesting as an acute painless lump of the jaw. Pediatrics, 85(5):858-64, 1990

Finley, A. M. \& Beeson, M. S. Actinomycosis osteomylelitis of the mandible. Am. J. Emerg. Med., 28(1):118.e1-4, 2010.

Foster, S. V.; Demmler, G. J.; Hawkins, E. P. \& Tillman, J. P. Pediatric cervicofacial actinomycosis. South Med. J., 86(10):1147-50, 1993.

Gannepalli, A.; Ayinampudi, B. K.; Baghirath, P. V. \& Reddy, G. V. Actinomycotic osteomyelitis of maxilla presenting as oroantral fistula: A rare case report. Case Rep. Dent., 2015:689240, 2015.

Goldberg, M. H. Diagnosis and treatment of cervicofacial actinomycosis. Oral Maxillofac. Surg. Clin. North Am., 15(1):518, 2003.

Hall, V. Actinomyces--gathering evidence of human colonization and infection. Anaerobe, 14(1):1-7, 2008.
Hirshberg, A.; Tsesis, I.; Metzger, Z. \& Kaplan, I. Periapical actinomycosis: a clinicopathologic study. Oral Surg. Oral Med. Oral Pathol. Oral Radiol. Endod., 95(5):614-20, 2003.

Jacobs, R. F. \& Schutze, G. E. Actinomycosis. In: Berhman, R. E. (Ed.). Nelson Textbook of Pediatrics. $16^{\text {th }}$ ed. Philadelphia, W. B. Saunders, 2000.

Kaplan, I.; Anavi, K.; Anavi, Y.; Calderon, S.; Schwartz-Arad, D.; Teicher, S. \& Hirshberg, A. The clinical spectrum of Actinomycesassociated lesions of the oral mucosa and jawbones: correlations with histomorphometric analysis. Oral Surg. Oral Med. Oral Pathol. Oral Radiol. Endod., 108(5):738-46, 2009.

Meethal, A. C.; Pattamparambath, M.; Balan, A.; Kumar, N. R. \& Sathyabhama, S. Actinomycotic osteomyelitis of the maxilla - A delusive presentation. J. Clin. Diagn. Res., 10(7):ZJ01-3, 2016.

Miller, M. \& Haddad, A. J. Cervicofacial actinomycosis. Oral Surg. Oral Med. Oral Pathol. Oral Radiol. Endod., 85(5):496-508, 1998.

Moreno Villalobos, D.; Paniura Rodriguez, D.; Huamani Parra, J. \& Barreto Almea, A. Osteomielitis mandibular por actinomices: Reporte de caso. Rev. Estomatol. Hered., 22(4):223-7, 2012.

Pulverer, G.; Schütt-Gerowitt, H. \& Schaal, K. P. Human cervicofacial actinomycoses: microbiological data for 1997 cases. Clin. Infect. Dis., 37(4):490-7, 2003.

Robinson, J. L.; Vaudry, W. L. \& Dobrovolsky, W. Actinomycosis presenting as osteomyelitis in the pediatric population. Pediatr. Infect. Dis. J., 24(4):365-9, 2005.

Rubin, M. M. \& Krost, B. S. Actinomycosis presenting as a midline palatal defect. J. Oral Maxillofac. Surg., 53(6):701-3, 1995.

Sharkawy, A. A. Cervicofacial actinomycosis and mandibular osteomyelitis. Infect. Dis. Clin. North Am., 21(2):543-56, 2007.

Vorasubin, N.; Wu, A. W.; Day, C. \& Suh, J. D. Invasive sinonasal actinomycosis: case report and literature review. Laryngoscope, 123(2):334-8, 2013

Wadhera, R.; Gulati, S. P.; Garg, A.; Ghai, A. \& Kumar, S. Frontal sinus actinomycosis presenting as osteomyelitis of frontal bone. Otolaryngol. Head Neck Surg., 138(4):544-5, 2008.

Corresponding author:

Nicolau Conte Neto

Department of Oral Surgery - UFPA

Augusto Correa Street, 01

Belem

BRAZIL

E-mail: conteneto@hotmail.com

Received: 14-07-2017

Accepted: 06-01-2018 